\title{
Music as an Element of Narration in Poetic Documentaries
}

\begin{abstract}
Music, sound and rhythm, as aesthetic means of design, have been part of the tradition of poetic documentary film from its early history. This paper discusses various examples of this genre, all of which use soundscapes, sound design, and music. Music can be either specially composed for the film or previously published. Internationally known for their musical and poetic qualities are films such as Man with a Movie Camera (Dziga Vertov 1929), Rain (1929) by Joris Ivens, and Berlin, Symphony of a Great City by Walter Ruttmann (1929), to name but a few outstanding examples. Among the most recent documentaries using music as a narrative element are The End of Time by Peter Mettler (2012) and Pearl Button by Patricio Guzmán (2015). The notion of music and rhythm as embodying meaning also applies to silent films, such as Manhatta (Strand and Sheeler 1921), a poetic documentary about Manhattan.

'Poetic documentaries' use sounds of the environment as well as music to convey a dramaturgical meaning. How these sounds inform the conceptualisation and realisation of creative/poetic documentaries is the central focus of this paper.
\end{abstract}

\section{KEYWORDS}

poetic documentary sound design music rhythm auteur cinema 
Documentary is a 'soft term,' similar to love or culture, 'always relational or comparative' (Nichols 2001: 20). To discuss the use of sound and music as a poetic element of documentary film, this article is structured into three parts. The first part is a short overview and outline of the paper's basic premises. In the second part, some examples from my own practice as a filmmaker working with sound and music are described. The last part focuses on some contemporary documentaries which are of particular interest to this thesis.

The tradition of documentary films begins with what we define today as 'poetic documentary.' It charts its development during the early 1920 s (cf. Nichols 2001: 88), as part of the avant-garde movement. Before that time, short non-fictional films were being made, such as films by the brothers Skladanovsky and Lumière. Das boxende Kängeruh (Skladanovsky 1895) or L'arrivée d'un train en gare à La Ciotat (Lumière and Lumière 1896) are examples.

Such short films, produced before 1919, have been labelled as 'views' or simply 'early non-fiction' (Gunnings 2003). Films such as these are taken to be the roots of documentary filmmaking, produced with different approaches from those later developed after World War I.

Within poetic documentaries, the level of visual design, or photogénie (cf. Chanan 2007: 98), is at the centre. Words, presented as intertitles dialogue, monologue and/or commentary-are additional elements designed to support the visual narration when necessary, contrasting to the production values of many of today's non-fiction formats. Showing, telling and poetics are the core elements of such documentaries (Nichols 2001: 88). Chanan describes documentary as:

... not dramatic but photogenic, rhetorical, metaphorical and poetic. Successive shots follow a logic of implication where, in place of plot and story, the organising principle is rhythm, rhyme and persuasion in its various modes - assertion, contention, polemic, dialectic. (Chanan 2007: 100)

Thus, a dramaturgical approach may be an appropriate method for analysing and describing the structure and aesthetics of the films below. Dramaturgy is a method, based on dialectic thinking (Adorno 2010), reflecting all elements of a film production, not only the narrative (Hasche, Kalisch, and Weber 2014; Stutterheim 2015).

Poetic, documentary filmmaking, as we understand the genre today, developed during the 1920s (Ellis and McLane 2005). This tradition started with films such as Manhatta (Strand and Sheeler 1921) and Nanook of the North (Flaherty 1922). Manhatta can be described as a visual poem. The rhythm of this short film is simple but effective. The film is centred on a poem. Each of the intertitles shows a verse of this poem over the silhouette of Manhattan, thus giving the film its basic rhythm. Between the titles, static shots alternate between views of crowded active streets scenes with more static situations. The camera was not only dependent on the use of a tripod but also limited by a fixed lens. Movements are therefore restricted. 
In this film, the technical conditions of the time, which nevertheless represented a technical advancement, were used to create visual poetics.

The filming and editing style reflects the rhythm of the metropolis. Within the first sequence one can see masses of workers arriving by ferry and streaming into the city. Later in the film, the focus moves to the rhythmic movements of workers and machines, which are contrasted with shots of static skyscrapers. Another sequence combines a steam locomotive just before its departure from a station with steamships on the Hudson River. Watching Manhatta one can imagine the soundscape and the rhythm of machines, cars, people, trains and ships. The rhythm and sound we experience resonates within our bodies and our surroundings. Rhythm is part of our life. Hence rhythm is the existential part of structure and narration, thus of dramaturgy too.

Since sounds and music are not only heard but resonate through our skin and sometimes our whole body, they imprint upon us in many ways and can be the trigger for memories. Referring to these memories through visual and/or sonic signals makes a deep impact onto our imagination. There is a body-memory reacting to pictures of trains, rivers, ships and machines. Paraphrasing Kant's dictum about the effect of great art on our bodies (Kant [1790] 1974: 272), one might say that our body reacts to sound and music, in such a way as to help trigger memories from visual representations of these sounds.

Listening and hearing are the most intense senses. 'The sense of hearing cannot be closed off at will. There are no earlids. When we go to sleep, our perception of sound is the last door to close and it is also the first to open when we awaken' (Schafer 1997: 11). Sound, being the most influential of our memories, effects body memory, which not only recalls trauma but also evokes memories of other emotional events (cf. Emrich 2014).

Embodied experiences, such as the sounds of trains, ships etc., are part of our sense of familiarity, of our knowledge (cf. Kahneman 2012). Thus, a visual reference to a sonic situation can evoke a memory - a vivid recreation of sounds and rhythms we might not be actually hearing. This happens as well when we are watching a movie or documentary with an emotive soundtrack. 'Hearing is a way of touching at a distance and the intimacy of the first sense is fused with sociability whenever people gather together to hear something special' (Schafer 1997: 11). From the example of Manhatta, albeit a silent film, one can get an idea of the correspondence of soundscape and visual narration, which is akin to elements of the City-Symphonies, avant-garde films portraying the life of cities such as Moscow, Amsterdam or Berlin.

Poetic documentary became established with films such as De Brug/ The Bridge (Ivens 1928), Regen/Rain (Ivens and Franken 1929), Человек с киноаппаратом/Man with a Movie Camera (Vertov 1929) and other 'City-Symphonies' as well as such films as the compilation film The Fall of the Romanov Dynasty (Schub 1927) and Turksib (Turin 1929). These films represent their genre by concentrating 'on detail, public sphere interaction of subjects, and plot simplicity, as much as on the authenticity of the documentary actor, his or her actions, and the locations' - the 'documentary 
essence' (Winston 2008). Grierson defined this approach as 'the creative treatment of actuality' (Grierson and Hardy 1947: 64). These definitions reflect the approach of new artistic movements after World War I, responding to catastrophe, devastation, horror and starvation, developing in central Europe a new style called Verism, and Magischer Realismus (Magic Realism) (cf. Gunther 1995). The latter become known in painting and graphics as Neue Sachlichkeit (New Objectivity), and Neues Sehen (New Vision) in photography (cf. Michalski 1994). These were the layers from which such documentary film started, alongside the political and social situation of post-war Europe.

Due to this specific artistic relationship, documentary films are informed by specific 'language processes', and do not necessarily have to be 'narrative' as in the sense of drama (Chanan 2007: 96-101). All these films consciously use rhythm and music, although they were produced during the era of silent film - which was nearly never really silent (Koerber, et al. 2001). During the 1920s, cinema orchestras performed scores written for specific films; in smaller movie theatres pianists, sometimes small ensembles, improvised on the rhythm of the film, or sometimes a definite selection of a standardised collection of gramophone records were played.

The most important and inspiring documentary from that period is Vertov's Man with the Movie Camera (Vertov 1929). This film is often named and referred to as the best documentary film of all time. Dziga Vertov, 'one of the world's most influential film artists' (Davis 2005: 15), studied music at Białystok Conservatory, where he founded a 'Laboratory of Hearing', before his family had to flee to Petrograd during WWI. He began his career as an editor for newsreels in 1917 and in 1918 became a filmmaker. Thus, it is not very surprising that he referred to music in his most successful documentaries-Man with a movie camera and Enthusiasm (1930). In both films, Vertov combined music and soundscape, perhaps as an early version of musique concréte. It is not only due to the futuristic and avant-garde approach of Vertov's film, Man with a Movie Camera, that one can feel 'the necessity of music' (Taniguchi 2005: 160). This film is dedicated to rhythm, in this case the rhythm of modern life in a city of the young Soviet Union. A model city is depicted, an amalgam of Moscow, Odessa and Kiev combined into one Soviet city. The music gives the film it's special atmosphere, which one can easily understand when seeing the restored version (Vertov 2000); or looking at all the new soundtracks produced by musicians attracted by the musicality of the film, such as Michael Nyman, In the Nursery, or The Cinematic Orchestra. Vertov refers to music from the beginning. The story within the story is introduced by observing a real orchestra, situated in the orchestral pit of a real cinema, which starts to play when the projection begins.

Through Vertov's cinematic style, music and the sound, with its traffic and industry, connected in our minds, in our imaginations, from the moment the central action begins. When all seats of the cinema are taken, the orchestra begins to play the moment the projection starts, the cinematographer steps through the screen into the city, taking us on a trip. The film tells the story of a cinematographer observing a day in a city. It is early 
morning and everything is still calm. The city sleeps, like the young woman in her bed or the homeless on his bench. A clock is ticking. Then the city awakes, trams leave the station, shops open, people wake up and hurry to work. The film follows the rhythm of a day in a city and it ends in a bar, with people drinking and dancing to music.

'The Kiev and Moscow premieres of Man with a Movie Camera employed orchestras, using Vertov's detailed cues for musical themes, instrumentation, and tempo changes. After a brief theatrical run, the documentary became scarce within the Soviet Union' (Darr 2010). Although the original score had been lost, Vertov's notes on the soundtrack were discovered and used for its later reconstruction. The Pordenone Silent Film Festival commissioned The Alloy Orchestra to compose a score following Vertov's musical instructions and notes (Darr 2010). Although the music employs contemporary instruments and gestures, this version remains the closest possible reconstruction of Vertov's original intention.

Another key example of poetic documentary concerning the use of music is Regen/Rain by Joris Ivens (1929). As well as being an avant-garde film, Regen was also edited with respect for the rhythm of a city, in this case by observing the dynamics of movement caused by rain. Ivens composed a visual narration in the 'New Vision' style, derived from photography, and influenced by the works of Laszlo Moholy-Nagy and Germaine Krull. Unlike Vertov, Ivens directed the film at first without any musical or sonic intentions, rather simply as a piece of dramatic visual art (Brunel 1999: 195).

Lou Lichtveld wrote the first score for Regen in 1932. Hanns Eisler later composed a new score in 1941, replacing the earlier version. Eisler's score is also known as a piece of chamber music, Vierzehn Arten den Regen zu beschreiben/Fourteen ways of describing rain (Eisler 1941). This score by Eisler supports a dramatic reading of the action without being merely illustrative.

Eisler's composition was part of a research project examining the relationship between music and film, on which Eisler worked from 1940 to 1942. The project was financed by the Rockefeller Foundation and connected to the New School of Social Research in New York, where Hanns Eisler and Theodor W. Adorno were members of staff. As another result of this research project, Eisler and Adorno published in 1947 Komposition für den Film/Composing for the Films (Eisler 1941). This publication as well as the interviews published in Hanns Eisler: Gespräche mit Hans Bunge (Eisler [1947] 1975), gives some understanding of the close connection between author, composer and director within a film or theatre production.

Thus, we have these two pathways within this tradition: the director establishing music and sound in the filmic narration from the beginning; or a director reflecting rhythm and thus our embedded experience of sounds through visual narration and developing the score in later cooperation with a composer.

From the emergence of sound movies, the use of music as part of the narration in documentary filmmaking has seemed natural. Examples of such music-dominant documentaries are: Night Mail (Watt and Wright 1936), the music composed by Benjamin Britten, sound design by W.H. Auden 
and Alberto Cavalcanti; Listen to Britain (Jennings and McAllister 1942), musical director Muir Mathieson; Koyaanisqatsi (Reggio 1982), music composed by Philip Glass (Glass 2000), and others.

To demonstrate how this use of music continues to be part of the practice, I offer a short reflection of how and why Niels Bolbrinker and I are developing and directing documentaries with regard to using music. The use of music is a specific decision made for every film, giving consideration to theme, topic or focus. Perhaps I should mention here that in Germany, Switzerland, France and many other European countries, documentaries are still produced primarily for cinema release before being broadcast. All of the examples below have been shown at festivals and have first had a cinema, festival or non-TV distribution.

Our collaboration began with Die Wäscherei - Ein Herz für Umwelt und Gewebe/The Laundry - A Heart for Environment and Textile 1992). I was the director, Bolbrinker the cinematographer. For this film, I decided to use only sound design, no music. A laundry is full of noise and sound. With this in mind, the sound recordist and sound designer, Manfred Herold, arranged the atmospheric sounds to support the action rather than being just illustrative. The viewer meets our protagonists at places were one would experience heat and noise, through the sound of the environment. Composed music would have been inappropriate here, being an irritant, changing how the audience read the scene. The whole film was arranged as a metaphor, an extraordinary situation of extreme change and what was happening to many others in our society. Therefore, it was important to give the impression of closeness, of familiarity and belonging. Not only was there no need for music but it would have destroyed the focus on this particular social entity.

For our film ORiginal WOlfen (1995), about the history of a manufacturer of film stock, co-directed by both of us and premiered at Berlinale 1996, we combined sound design and music. This was important for more than one reason. First, there is the location sound - we were filming in the area where from 1909 until the early 1990s the most important manufacturer for photographical and film material was situated. Film productions and photographers all over the world used their products, first known as Agfa, later ORWO. In 1995, the centenary of cinema was celebrated. This was also the year that this factory was demolished, despite the fact that the process of getting the factory declared as a cultural heritage was still being argued. The factory was an important example of modern industrial architecture. The main parts of the site were built in the modern style of that time. These old buildings, dating from 1909, were all clad in the yellow brickwork typical of that area. We had to adapt our schedule for filming against the demolition work. Thus, the sound design was arranged as a dialectic between noise and silence.

To give an idea of the trajectory of historical changes, we used examples of music from the specific times, or kept the source music from the archive material included in the film. For example, to depict the early, more prosperous era of this industrial region, called Mitteldeutsches Industrierevier - Industrial Belt of Middle-Germany-we chose, for 
example, Kurt Weill's Berlin im Licht/Berlin Lit Up (Weill 1928). This composition had been commissioned in 1928 by AEG, at that time the biggest and most important energy supplier in Germany. Berlin im Licht premiered during a 'festival of light' all over Berlin in 1928. It reflected the spirit of the time, of a prosperous and culturally vital Berlin, the achievements of modern industry, and the spirit of modernity. Thus, this was a great opportunity for giving an artistic impression of the time as well as the connection between film and light, and between the film industry and energy suppliers.

To depict times nearer our own, we used the jazz-pop music from original advertisements made at the time showing that the film factory was rebranded as ORWO ('Original Wolfen'). This archive material represented the short period of socialist optimism, of becoming independent from Agfa, and even so continuing as the internationally successful manufacturer it had always been. To underline the contrast, we went back to sound design, to express the time of stagnation, and to express the gradual dismemberment of the company and the unemployment of its former workers. Within our concept for composing a visual and sound narration, we arranged these narratives in a dialectic relationship with each other. Thus, we hoped to give the audience not only information but also an emotional impression of this time and place.

From the beginning, music was at the core of our documentary, The Thuranos - Just a Matter of Balance (2003). Our protagonists were a family of variety artists; music was an integral part of their work and life. When we developed the concept for this documentary, it became obvious that the show itself would comprise one central level of narration. Using the performance as an ongoing event gave a stability to the narration and at the same time offered the opportunity to construct a more open form. This further allowed us to explore our protagonist's biography and the story of his family as an entertainment troupe, interspersed within the show. The challenging elements were not so much the age of our protagonist (who was 92 years old when we started the project) but issues having to do with the music that was performed as part of the show. The troupe was using music for which we would never have enough budget to buy the film rights. To solve this problem, we contacted the film music composer Stefan Warmuth. He was the musical director and conductor of the orchestra for that particular variety-theatre Wintergarten in Berlin, the same one in which Thuranos performed for several weeks. Together we developed a concept for a score connecting the performance with the biographical sequences. That approach gave the composer the opportunity to adapt some of the variety themes as well as its musical atmosphere, and integrate these in a film score supporting the overall dramaturgical structure. To keep Stephan Warmuth updated we met regularly during the editing process and discussed ideas and themes. Thus, from the beginning, the opening section would have music introducing the main theme, as well as our approach and our directorial mood for this film. Niels Bolbrinker suggested that using Ry Cooder's Happy Meeting in Glory (Cooder 1978) would be a way of introducing our 'voice' in the film. We thought this song would give the whole film a good keynote. Keynote is also a musical term. 
'It is the note that identifies the key or tonality of a particular composition. It is the anchor or fundamental tone and although the material may modulate around it, often obscuring its importance, it is in reference to this point that everything else takes on its special meaning. Keynote sounds do not have to be listened to consciously; they are overheard but cannot be overlooked, for keynote sounds become listening habits in spite of themselves.' (Schafer 2011: pos. 256/6308)

Another situation for which we had consequently to choose music was a moment of deep emotional impact, a situation one could not depict with words or a commentary. It was beautifully shot, but since music was part of the narrative, we had to find a musical equivalent which could hold the atmosphere without becoming 'kitschy'. One of our protagonists, Sabine, who was born and grew up in South Africa, remembers a wonderful childhood there. She was visiting the place after decades, again sitting in the afternoon sun and lost in her memories. Just watching her is touching. To give that situation an atmospheric sound in order to integrate the sound of a landscape, I chose a title from a CD of contemporary music from South Africa. Here again Warmuth followed the main gestural language and instrumentation of it, to keep its implicit meaning. Every sequence had its specific sound but each sound was an integral part of the whole process and thus of the final work.

For Fliegen und Engel/Flies and Angels (Stutterheim and Bolbrinker 2009), the documentary about Ilya and Emilia Kabakov and the art of 'total' installation, I decided a different way of using music and sound. As before, music and sound were part of the overall concept for the film. My aesthetic approach for this film was to adapt the postmodern-ironic aesthetic of the Kabakovs' work into our filmmaking. The Kabakovs' work plays a game with the porous and blurred boundary between reality and fantasy. They present difficult situations, but do it in a way which makes their audience smile at the subtlety.

Thus, my dramaturgical concept was to set selected artworks by the Kabakovs in relation to their biography, as well as to the cultural and political circumstances of their time, and to blur the distinction between reality and fantasy through cinematography, sound design and editing. Flies and Angels is a film about memories, fears and hopes; past, present and future. We decided that within the genre of poetic documentary we should produce a dramaturgical concept connecting all the elements of the cinematic design in such way as to give the film its own particular aesthetic. Consequently, we decided to use atmospheric sound and only the music the Kabakovs used in their own work, as for example in the sequence of watching people stroll through a dark room, torches in hand, to discover through the torches' beams the installation Mother and Son (Kabakov 1990). Here we can also hear Ilya Kabakov himself singing as it is part of the installation.

For the title sequence, we used the musical material sounding in the installation The Red Wagon (Kabakov and Kabakov 2008). He had chosen a selection of songs from the 1930's/1940's that were originally arranged by 
Vladimir Tarasov for The Red Wagon, version 1 (Kabakov and Kabakov 1999). These were 'songs filled with extraordinary courage, energy, bright lyrical feeling' (Kabakov and Kabakov 2001). By combining this nonillustrative music to the editing of the scene, the audience is encouraged to activate their own imaginations. This had been introduced in the very first scene, as a prelude, announcing a piece of art, inviting the audience to watch and dream. Here again we were referring to the concept of using a 'keynote' to present our voice without necessarily having to be present in person.

Related to what I have been describing from my own work and the tradition on which it is based, some recent films may provide good examples of today's development in poetic documentaries.

El Botón de Nácar/The Pearl Button by Patricio Guzmán premiered at the Berlinale 2015 competition and was awarded with a Silver Bear for the Best Screenplay (as well as ten other awards worldwide). The film has not only a convincing verbal narration but is similar to Nostalgia de la Luz/Nostalgia for the Light (Guzmán 2010), the first film of a trilogy of remarkable poetic and cinematic quality. Guzmán here worked with Miranda y Tobar as well as Hughes Maréchal. Miranda y Tobar is a music studio in Chile. José Miguel Miranda and José Miguel Tobar had been composing and producing for TV and cinema since the early 1990s. Hughes Maréchal is a Belgian composer known for scoring for documentaries since 1999.

Nostalgia de la Luz is structured according to the dialectic rhythms of sky and desert, history and future. The Pearl Button's landscape, natural conditions, history as well as present, are set into a dialectical relationship. Within this documentary, water plays a major element. It is a reference point from a geographical point of view, but is also an essential natural element of our lives.

The title sequence contains a quotation from Raúl Zurita: 'We are all streams from the water' (Guzmán 2015), and the very first sequence examines a quartz cube, which is about 3000 years old, containing a drop of water inside. That quartz was found in the Atacama Desert. Due to it being the driest place in the world, the Atacama Desert is a favoured location for astrophysical institutes. From here, astronomers discovered water throughout the entire cosmos. On Earth water is essential for life. Developing the epic storyline of this contrast between earth and cosmos, water is the 'keynote' of this documentary, illuminating this molecule as the moment of convergence.

Consequently, water and its sound as well as sounds we associate with appearances or manifestations of water, are central to the sonic design in this documentary. This continues from the first sequence through to the appearance of one of the film's protagonists, Claudio Mercado. Mercado is an anthropologist, whom Guzmán met through his research. This anthropologist has studied the knowledge systems, beliefs and traditions of the Native Chileans. Their fate, brought about by the dictatorship of Pinochet, is the story at the centre of this documentary. Mercado reflects on sound as part of our experience of life and nature. He not only talks about water as a source of music, and about the language of water, or about the particular sound of a river; he also interprets water musically through overtone singing, which he learned from the Native Chileans. Thus, the 
film's major motif and its transformation into sound design is connected with the conceptual function of music. The abstraction and transformation of this 'keynote' is brought about through the singer and the composer. The singer and the editing of original sounds or atmospheric sounds come first, and the composer's work follows in relation to this.

One can hear sounds reminiscent of foghorns, waves, winds, storms, the melodies of streams and rivers, the sound of the ocean - or of hail and rain, light and heavy, raindrops drumming on a roof, cracking and melting ice.

When Guzmán began the editing process with editor Emmanuelle Joy, they used temp-track music for the cut, and this was sent to the composers. When the composers received each cut, Guzmán described what theme, atmosphere or orchestration he wanted. The temp track music served as orientation. Given this, the composers offered musical sequences to Guzmán. Every music cue was listened to, tested, discussed - until a final solution was found. In this way the original music was developed out of the film, in an organic way. As Renate Sachse, the film's producer, describes it, this is a process of growing. At the end everything was recorded as agreed and last adjustments were made in the sound-mix (Sachse 2016). Altogether, the music in The Pearl Button is very much jazz, not only because of the musical design using jazz rhythms, instrumentations and sound. Guzmán often compares making a documentary with playing jazz, in its openness, nothing completely closed but just fading in and out between moments.

Another example, following the tradition from Vertov to Guzmán, is The End of Time by Peter Mettler (2012). In his film Mettler wanted the audience to be aware of watching a film. In this he chose a postmodern film aesthetic (cf. Stutterheim 2013: 122). To achieve this he adapted an artistic invention Vertov introduced in Man with a Movie Camera, that of intercutting and interrupting one narrative with another, which became the filmic equivalent to the alienation effect which later was defined by Brecht.

The End of Time is a film 'about perception and awareness. It offers a challenge to see through our conceptual thinking' (Mettler 2012: 5). And that refers to our concept of time, which is different according to particular circumstances, different cultural traditions or geographical regions. Mettler discovers the perception and reception of time and how concepts of time influence our lives. Like Guzman, he directed the film as an audio-visual composition (Entrevue 2012).

The film first tunes the viewer into concepts of time, but then leaves the world of ideas and takes them through an experience of time, which is not unlike that of listening to music, with the intention to provoke a heightened awareness and associative thinking process (Mettler 2012).

As with Guzmán's films Nostalgia of the Light and The Pearl Button referred to above, its quality is defined by both the cinematography and the sound-music-design. The sonic composition of the first sequence demonstrates this clearly. We are presented with archive footage of the American astronaut, Joe Kittinger, as he jumps from a balloon at the edge of space. This is accompanied by a sound design which transforms the feelings Kittinger remembers from this jump into an associative sound - a spherical sound, 
breathing through a breathing apparatus, wind. The sonic design is inspired by Techno music, which Mettler sees as 'emblematic of the digital age, so it's interesting to see this digital form come out of this wasteland of the industrial age' (Anderson 2012). These thoughts about Techno music become most evident in the Detroit-Sequence (60-65 minutes into the film), but are true for the film's entire sonic concept. Mettler composed a 'dense and intricately designed soundtrack, which integrates natural sources with original music by a variety of composers including Autechre, Thomas Köner and Plastikman (the latter's alter ego Richie Hawtin is also featured as an onscreen subject)' (Anderson 2012). For sequences depicting natural phenomena, he mixes atmospheric sound with electronic music, which amplifies what the audience sees, such as the thunderstorm (27-28 minutes in) or the lava sequence (at 39 and 41- 46 minutes). He also decided that music which seems organic to one situation can be abstracted and used in another, which may be disconnected in time and space. In that way he was able to establish a correspondence between the VJ-sequence and the Detroit-sequence. This allows the reflection about experiencing the moment, the interaction of being human and machines, the virtual and real world.

Altogether, the soundtrack is a conceptual framework, which Mettler described this way:

In physics, when particles collide, they go out in a sphere. According to the Big Bang Theory, that's what created our universe, so everything in the universe is spherical. So it makes sense that you would make something round to meditate upon. It went up a notch when my friend Bruno Degazio and Christos Hatzis created this audiovisual composition called Harmonia (Mettler integrates it into the 'Mixxa' sequence). It's actually a picture of harmonics: there are 64 harmonics in all and each time there's an added harmonic, you get a line. So the second harmonic connects two points on the circle, the third harmonic three points on the circle, the fourth four, and so on up to 64. And you hear each of those harmonics as well. This goes back to ideas of Plato and the Music of the Spheres. So all this stuff started intertwining conceptually and visually - I don't have a thesis about it, but there seem to be a lot of relationships with these spherical patterns that we use in science and religion and now music as well. You start to connect all these dots together and offer that to the viewer as an experience, as part of the meditation (Anderson 2012).

A similar approach to Mettler's arrangement of sound in his film, can be found in Robert Mosse's Incoming (Mosse 2017). For this 3-channel documentary installation he collaborated with composer Ben Frost to blur ambient field sound with synthetic sounds into a visceral soundtrack.

By contrast, Gianfranco Rosi, in his film Fuocoammare (Rosi 2016) includes music as dramaturgical transition elements. In general, Rosi only uses location and originals sounds, but in this film, introduced through one of the characters who is the moderator of a local radio station, songs appears either to comment on the situation, to support emotionally the events, 
and/or to establish transitions between scenes. For this film, he worked together with composer Stefano Grosso.

Since poetic documentary are films combining a reference to reality, thus activating our consciousness, with an artistic approach directed towards our senses, the conceptual use of sound and music is highly important. Directors of documentary films, which are made for cinema distribution, usually work with a concept that connects the visual and the sonic level of narration as a unity. Music and sound design are an integrated part of the narration. This is true since the beginning of documentary filmmaking and will be of importance as long as documentaries are produced as films not just TV productions - be it for entertainment or with an educational remit. The distinction between poetic documentaries and TV documentaries can be explained in this way: poetic documentaries reflect reality as an artistic approach which concentrates not only on an actual event but are also metaphorical and universal. This artistic approach may account for their lasting fascination, as Man with a Movie Camera released in 1929 amply demonstrates. Thus, the poetic documentary style should be respected as an audio-visual, narrative-performative art form.

\section{SOURCES}

Adorno, T. W. ([1958] 2010), Einfübrung in die Dialektik (1st edit.), Frankfurt am Main: Suhrkamp.

Adorno, T. W. and H. Eisler (1947), Komposition für den Film/Composing for the Films, Frankfurt am Main: Suhrkamp.

Anderson, J. (2012), 'Lost in the moment: Peter Mettler on The End of Time', cinema scope: expanding the frame on international cinema, CS52. Retrieved from http://cinema- scope.com/cinema-scope-magazine/ lost-in-the-moment-peter-mettler-on-the-end-of- time/. Accessed 05.05.2017.

Bolbrinker, N. and K. Stutterheim (1995), ORiginal WOlfen. Aus der Geschichte einer Filmfabrik. / ORiginal WOlfen. From a History of a Film Manufacturer, Germany: Brandenburger Filmbetrieb.

Brunel, Claude (1999), 'Music and Soundtrack in Joris Iven's Films, in Joris Ivens and the Documentary Context, edited by Kees Bakker, Amsterdam: Amsterdam University Press, pp. 195-209.

Chanan, M. (2007), The Politics of Documentary, London: BFI.

Cooder, Ry (1978), 'Happy Meeting in Glory', in Jazz, USA: Warner Bros. Records.

Darr, B. (2010), 'Man with A Movie Camera', San Francisco Silent Film Festival, from http://silentfilm.org/archive/man-with-a-movie-camera. Accessed 30.04.2017.

Davis, J. (2005), 'Vertov Nation', in D. Robinson and L. Giuliani (eds.), The Collegium Papers VI - The Pordenone Silent Film Festival, Sacile: Film Intelligence, pp. 15-68.

Eisler, H. (1941), Vierzehn Arten den Regen zu beschreiben: opus 7, Variationen für Flöte, Klarinette, Violine, Viola, Violoncello und Klavier, music, Leipzig/London/New York: Edition Peters. 
Eisler, H. (1975), Gespräche mit Hans Bunge: Fragen Sie mehr über Brecht, Berlin: Akademie der Künste zu Berlin.

Ellis, J. C. and B. A. McLane (2005), A New History of Documentary Film, New York: Continuum.

Emrich, Hinderk M. (2014), 'Postmoderne Filme als Repäsentation der Tiefendimensionen von Wharnehmung und Bewußtsein', in Come and Play with us - Dramaturgie und Ästhetik im postmodernen Kino, edited by Kerstin Stutterheim and Christine Lang, Marburg: Schüren, pp. 88-110.

Entrevue (2012), The End of Time - Interview with Peter Mettler, from https://www.youtube.com/watch?v=L16-caoWwPM. Accessed 28.04.2017

Flaherty, Robert J. (1922), Nanook of the North, film, USA/France: Les Frères Revillon, Pathé Exchange.

Glass, Philip (2000), 'Philip Glass on Koyanisqatsi and Powaqqatsi', in D. Morgan (ed.), Knowing the Score: Film Composers Talk About the Art, Craft, Blood, Sweat, and Tears of Writing for Cinema, New York: Harper Entertainment, pp. 141-152.

Grierson, J. and F. Hardy (1947), Grierson on Documentary (1st American ed.), New York, Harcourt.

Gunnings, T. (2003), 'Ansichten im frühen Kino', in F. H. Kessler (ed.), KINtop. Jabrbuch zur Erforschung des frü̈hen Films (Vol. 12). Frankfurt/Main: Stromfeld Verlag.

Gunther, Irene (1995), 'Magic Realism, New Objectivity, and the Arts during the Weimar Republic', in Magical Realism: Theory, History, Community, edited by Lois Parkinson Zamora and Wendy B. Faris, Durham and London: Duke University Press, pp. 33-74.

Guzmán, P. (2010), Nostalgia De La Luz / Nostalgia for the Light, film, Chile: Atacama Productions.

Guzmán, P. (2015), El botón de nácar / The Pearl Button, film, Chile: Atacama Productions.

Hasche, C., E. Kalisch and T. Weber (eds.) (2014), Der dramaturgische Blick: Potenziale und Modelle von Dramaturgie im Medienwandel, Berlin: Avinius Verlag .

Ivens, J. (1928), film De Brug/The Bridge, film, Netherlands: Capi-Holland. Ivens, J. and M. Franken (1929), Regen / Rain, film, Netherlands: Capi-Holland.

Jennings, H. and S. McAllister (1942), Listen to Britain, film, UK: Crown Film Unit.

Kabakov, Ilya (1990), Mother and Son, installation, Switzerland, Basel: Collection Emanuel- Hoffmann.

Kabakov, Ilya and Emilia Kabakov (1999), The Red Wagon - Version 1, installation, Wiesbaden: Museum Wiesbaden.

Kabakov, Ilya and Emilia Kabakov (2008), The Red Wagon - Version 2, installation, Moscow: Collection The Hermitage Museum.

Kahneman, D. (2012), Thinking, Fast And Slow (1st edit.). London: Penguin Books.

Kant, Immanuel ([1790] 1974), Kritik der Urteilskraft, Frankfurt am Main: Suhrkamp. 
Koebner, M. and H. Theuerkauf (eds.) (2001), 'Beiwerk zum Flimmerbilde?': Musik zu stummen Filmen. Vol. 7, FilmHeft, Berlin: Filmmuseum Berlin - Deutsche Kinemathe.

Lang, Fritz (1927), Metropolis, film, Germany: UFA.

Lumière, A. and Lumière (1896), L'arrivée d'un train en gare de La Ciotat, film, France: Société Lumière.

Mettler, P. (2012), The End of Time - Press Kit.

Mettler, P. (2012), The End of Time, film, Canada/Switzerland: Grimthorpe Film, Maximage GmbH, National Film Board of Canada.

Michalski, Sergiusz (1994), Nerw Objectivity: Painting, Graphic Art and Photography in Weimar Germany, 1919-1933, Köln: Benedikt Taschen.

Mosse, Richard (2017), Incoming, film, UK: Mosse.

Nichols, B. (2001), Introduction to Documentary (2nd edit.), Bloomington: Indiana University Press.

Reggio, G. (1982), Koyaanisqatsi: Life out of Balance, film, USA: Ire Productions.

Rosi, Gianfranco (2016), Fuocoammare / Fire at Sea, film, Italy: Stemal Entertainment, 21 Unofilm, Istituto Luce Cinecittà.

Ruttman, Walter (1927), Berlin: Die Sinfonie der Grosstadt / Berlin: Symphony of a Great City, film, Germany: Deutsche Vereins-Film, Les Productions Fox Europa.

Sachse, R. (2016), Fragen zu Musik und Sound in Guzman's Filmen, email. Schafer, R. M. (1997), The Soundscape: Our Sonic Environment and the Tuning of the World, Rochester, Vt.: Destiny Books; ebook version 2011.

Schub, Esfir Iljinitschna (Шуб, Эсфирь Ильинична) (1927), Падение династии Романовых / The Fall of the Romanov Dynasty, film, USSR: Museum of the Revolution, Moskwa.

Skladanovsky, Max (1895), Das boxende Kängeruh, film, Germany: Skladanovsky.

Strand, P. and C. Sheeler (1921), Manhatta, film, USA.

Stutterheim, K. (1992), Die Wäscherei - Ein Herz für Umwelt und Gerwebe I The Laundry - A Heart for Environment and Textile, film, Germany: Stutterheim Filmproduktion, ZDF.

Stutterheim, K. (2013), 'Überlegungen zur Ästhetik des postmodernen Films', in K. Stutterheim and C. Lang (eds.), Come and play with us Dramaturgie und Ästhetik im postmodernen Kino, Marburg: Schüren, pp. 39-87.

Stutterheim, K. (2015), Handbuch angewandter Dramaturgie. Vom Geheimnis des filmischen Erzählens, Frankfurt am Main: Peter Lang Verlag.

Stutterheim, K. and N. Bolbrinker (2004), Die Thuranos - Leben auf dem Drabtseil / The Thruanos - Just a Matter of Balance, film, Germany: Mteropolis Berlin, ARTE, NDR, WDR.

Stutterheim, K and N. Bolbrinker (2009), Fliegen und Engel: Ilya und Emilia Kabakov - die Kunst der 'totalen' Installation / Flies and Angels: Ilya and Emilia Kabakov - the Art of 'Total' Installation, film, Germany: Filmtank Hamburg, WDR.

Taniguchi, N. (2005), 'Music and silent film. Time-travel and cinematic-experience', in L. Giuliani and D. Robinson (eds.), 
The Collegium Papers VI: The Pordenone Silent Film Festival (pp. 160-164), Sacile: Film Intellect.

Turin, Victor Alexandrovitch (1929), Turksib (Туркестано-Сибирская железная дорога, Турксиб), film, USSR: Vostokkino.

Vertov, D. (1929), Man with a Movie Camera / Человек C Киноаппаратом, film, USSR: VUFKU.

Vertov, D. (1930), Enthusiasm: The Symphony of Donbass / Энтузиазм: Симфония Донбасса, film, USSR: Ukrainfilm.

Vertov, D. (2000), [1929] Man with a Movie Camera, Film, UK: BFI.

Watt, H. and B. Wright (1936), Night Mail, film, UK: GPO Film Unit.

Winston, B. (2008), Claiming the Real II: Documentary: Grierson and Beyond, London: British Film Institute.

Weill, Kurt (1928), Berlin im Licht / Berlin Lit Up (for voice and jazz band), music, USA: edited by Schott Music, European American Music Corporation, Universal Edition.

\section{CONTRIBUTOR'S DETAILS}

Kerstin Stutterheim is Professor of Media and Cultural Studies at Bournemouth University. Before her appointment in 2015, she held the post of Professor for Dramaturgy and Aesthetic of Audio-Visual Media at Film University Babelsberg 'Konrad Wolf'. She has been a filmmaker and producer since 1992 and a member of German Film Academy. Recent publications: Handbuch Angewandter Dramaturgy (Peter Lang Verlag 2015); Game of Thrones' sehen. (Fink Verlag/Brill 2017), and Modern Film Dramaturgy (Routledge 2018). For more information see orcid.org/ 0000-0002-5243-616X

Contact: k.stutterheim@icloud.com 


\section{Your short guide to the EUP Journals Blog http://euppublishingblog.com/}

A forum for discussions relating to Edinburgh University Press Journals

\section{The primary goal of the EUP Journals Blog}

To aid discovery of authors, articles, research, multimedia and reviews published in Journals, and as a consequence contribute to increasing traffic, usage and citations of journal content.

\section{Audience}

Blog posts are written for an educated, popular and academic audience within EUP Journals' publishing fields.

\section{Content criteria - your ideas for posts}

We prioritize posts that will feature highly in search rankings, that are shareable and that will drive readers to your article on the EUP site.

\section{Word count, style, and formatting}

- Flexible length, however typical posts range 70-600 words.

- Related images and media files are encouraged.

- No heavy restrictions to the style or format of the post, but it should best reflect the content and topic discussed.

\section{Linking policy}

- $\quad$ Links to external blogs and websites that are related to the author, subject matter and to EUP publishing fields are encouraged, e.g.to related blog posts

\section{Submit your post}

Submit to ruth.allison@eup.ed.ac.uk

If you'd like to be a regular contributor, then we can set you up as an author so you can create, edit, publish, and delete your own posts, as well as upload files and images.

\section{Republishing/repurposing}

Posts may be re-used and re-purposed on other websites and blogs, but a minimum 2 week waiting period is suggested, and an acknowledgement and link to the original post on the EUP blog is requested.

\section{Items to accompany post}

- A short biography (ideally 25 words or less, but up to 40 words)

- A photo/headshot image of the author(s) if possible.

- Any relevant, thematic images or accompanying media (podcasts, video, graphics and photographs), provided copyright and permission to republish has been obtained.

- Files should be high resolution and a maximum of $1 \mathrm{~GB}$

- Permitted file types: jpg, jpeg, png, gif, pdf, doc, ppt, odt, pptx, docx, pps, ppsx, xls, xlsx, key, mp3, m4a, wav, ogg, zip, ogv, mp4, m4v, mov, wmv, avi, mpg, 3gp, $3 g 2$. 